\title{
STRES KRONIS MENURUNKAN TEBAL LAPISAN SEL GRANULOSA FOLIKEL ANTRAL RATTUS NORVEGICUS
}

\author{
Alifia Candra Puriastuti ${ }^{1}$, Margarita M. Maramis ${ }^{2}$, Jimmy Januar Annas ${ }^{3}$ \\ ${ }^{1}$ Mahasiswa Ilmu Kesehatan Reproduksi Jenjang Magister, Fakultas Kedokteran, \\ Universitas Airlangga Surabaya \\ ${ }^{2}$ Departemen Ilmu Kesehatan Jiwa, Fakultas Kedokteran, Universitas Airlangga, RSUD \\ Dr. Soetomo \\ ${ }^{3}$ Departemen Obstetri dan Ginekologi, Fakultas Kedokteran, Universitas Airlangga, \\ RSUD Dr. Soetomo \\ e-mail : alifia.can.puriastuti-2016@fk.unair.ac.id
}

\begin{abstract}
ABSTRAK
Kondisi reproduksi seorang perempuan dapat dinilai dari keberlangsungan siklus ovarium dan siklus endometrium. Stres yang terjadi secara kronis dapat mempengaruhi siklus reproduksi tersebut. Folikulogenesis yang merupakan bagian dari siklus ovarium dipengaruhi oleh interaksi antara oosit, sel granulosa dan sel teka. Komunikasi ini bertujuan sebagai pemberi nutrisi dan sinyal pengatur yang diperlukan untuk maturasi. Tebal lapisan sel granulosa terutama pada fase folikel antral dapat digunakan sebagai marker homeostasis sel dalam mempertahankan keberlangsungan folikulogenesis. Membuktikan stres kronis dengan metode chronic unpredictable mild stress (CUMS) dapat menurunkan tebal lapisan sel granulosa pada Rattus novergicus. Unit sampel dibagi menjadi dua kelompok yakni kelompok kontrol tanpa stres dan kelompok perlakuan dengan CUMS 22 hari. Setelah 24 jam dari perlakuan terakhir, tikus dikorbankan dan dibuat preparat ovarium dengan pewarnaan hematoxilin eosin. Pengukuran secara histologi tebal lapisan sel granulosa folikel antral di bawah mikroskop dengan menggunakan mikrometer. Pengujian hipotesis dilakukan dengan uji Independent T-Test. Hasil uji dalam $\alpha=0.05$, nilai $T_{\text {hitung }}=2.540$, nilai

( ), dapat disimpulkan menolak $H_{0}$ (ada perbedaan signifikan). Maka dapat diartikan terdapat penurunan signifikan tebal sel granulosa folikel antral antara kelompok kontrol dibanding kelompok perlakuan. Stres kronis dapat menurunkan tebal lapisan sel granulosa folikel antral.
\end{abstract}

Kata kunci : stres kronis, tebal lapisan sel granulosa, folikel antral 


\begin{abstract}
Woman's reproductive could be determined by the continuity of the ovarian cycle and the endometrial cycle. Chronic stress could affect the reproductive cycle. Folliculogenesis which part of the ovarian cycle was affected by the interaction between oocytes, granulosa cells and theca cells. These two-way communication was expected to provide the nutrients and regulatory signals necessary for maturation. The granulosa cells layer thickness of antral follicle phase could be used as a cells homeostasis marker in maintaining the continuity of folliculogenesis. This study aimed to prove that chronic stress with Chronic Unpredictable Mild Stress (CUMS) method could reduce the granulosa cells layer thickness in Rattus novergicus. The sample units were divided into two groups: the stressless control group and the treatment group with 22 days of CUMS. After 24 hours of the last treatment, the mice were sacrificed and given an ovary preparation with hematoxylin eosin staining. The histologically measurement granulosa cells layer thickness in antral follicle using a micrometer. Hypothesis analysis was tested by Independent T-Test. The result in $\alpha=0.05, T$ value = 2.540, $p$ value $=0.024(p<\alpha)$, it could be concluded that $H_{0}$ was rejected (there was significant difference). Thus, there could be a significant decrease in the granulosa cells layer thickness of antral follicle between the control group and the treatment group. Chronic stress could decrease the antral follicle's granulosa cells layer thickness.
\end{abstract}

Keywords : Chronic stress, granulosa cells layer thickness, antral follicle 


\section{PENDAHULUAN}

Infertilitas menjadi masalah pada $10-15 \%$ pasangan dan menjadi hal penting bagi para klinisi (Fritz, 2011). Data prevalensi penyebab infertilitas pada perempuan menurut WHO, gangguan ovarium menempati prevalensi tertinggi, yakni sebesar 33\% dan gangguan folikulogenesis menjadi salah satu bagian penyebabnya (Bedaiwy et al., 2003; Myrnawati, 2012; Fitriani, 2016). Gangguan ovulasi dan gangguan folikulogenesis dapat terjadi akibat paparan stres dalam jangka waktu lama (stres kronis).

Stres juga dapat menyebabkan infertil sekunder dan berdampak pada kesehatan reproduksi perempuan di saat mendatang. Berbagai penelitian telah menyatakan bahwa stres terbukti dapat menyebabkan infertilitas, terutama stres yang terjadi secara terus menerus atau stres kronis (Whirledge, 2010; Hendarto, 2015; Setiyono, 2015; Li, 2017; dan Scarlet,2017).

Stres dan kecemasan dapat meningkatkan intensitas supresi Gonadotrophine Releasing Hormone (GnRH) dan berhubungan dengan meningkatnya disfungsi ovulasi (Fritz, 2011). Aktivitas Corticotrophine Releasing Hormone (CRH) yang berlebihan di hipotalamus, sebagai respon terhadap stres menjadi mekanisme untuk supresi GnRH. Selanjutnya, sebagai usaha tubuh dalam beradaptasi dengan stres menyebabkan diproduksinya suatu hormon glukokortikoid yaitu kortisol oleh kelenjar adrenal. Peningkatan kadar kortisol ini lah yang secara tidak langsung mengakibatkan gangguan pulsasi GnRH (Whirledge, 2010).

Gangguan pada aksis Hipotalamus - Pituitari - Ovarium (HPO) dapat berlanjut hingga terjadi gangguan ovulasi bahkan sampai dengan terjadinya gangguan folikulogenesis.
Folikulogenesis juga dipengaruhi oleh komunikasi dua arah antara oosit dan sel somatik terutama sel granulosa yang mengelilingi oosit (sel granulosa kumulus) untuk menentukan perkembangan oosit. Oosit bergantung pada sel granulosa untuk memberikan nutrisi dan sinyal pengatur yang diperlukan untuk maturasi inti dan sitoplasma (Gilchrist et al., 2008; Myrnawati, 2012).

Pada saat folikel mencapai fase antral, terbentuk kompleks sel granulosa - oosit atau disebut Kompleks Oosit - Kumulus (KOK) (Gilchrist et al., 2008; Myrnawati, 2012). Tebal lapisan tersebut dapat digunakan sebagai acuan homeostasis sel dalam mempertahankan keberlangsungan folikulogenesis, karena semakin sedikit jumlah prolifersi sel granulosa dapat mempengaruhi kualitas oosit (Gupta et al., 2008; Myrnawati, 2012).

Oleh karena hal diatas, penelitian ini bermaksud membuktikan bahwa stres kronis dapat mengakibatkan penurunan tebal lapisan sel granulosa folikel antral pada Rattus norvegicus model stres kronis.

\section{MATERI DAN METODE}

Penelitian ini merupakan penelitian laboratoris dengan Rattus novergicus sebagai model hewan coba stres kronis. Besar unit sampel hingga akhir penelitian adalah 16 ekor yang terbagi dalam dua kelompok, yakni kelompok kontrol dan perlakuan.

\section{Aklimatisasi}

Aklimatisasi bertujuan untuk memberikan kesempatan adaptasi bagi tikus dan dilakukan selama 7 hari. Tikus ditempatkan di kandang dan berkoloni $2-3$ ekor tikus dalam ruang penelitian yang sunyi tenang dan berventilasi. 


\section{Sinkronisasi Birahi}

Sinkronisasi birahi dilakuan pada hari ke delapan dan kesepuluh dengan melakukan penyuntikan PGF2 $\alpha$ (Lutaprost $^{\circledR}$ 250, Agrivet, USA) dengan dosis $25 \mu \mathrm{g} / \mathrm{g}$ BB secara intraperitoneal (Rosdianto, 2016). Tujuan dari sinkronisasi birahi yakni untuk penyamarataan fase estrus (Campbel, 2013), hingga saat dilakukan pembedahan.

\section{Pemaparan Stresor}

Rattus norvegicus model stres kronis adalah tikus yang berada pada kelompok perlakuan. Sedangkan kelompok kontrol digunakan sebagai pembanding dan dicegah mengalami stres.
Pemberian stres kronis dalam penelitian ini menggunakan metode Chronic Unpredictable Mild Stress (CUMS). CUMS adalah pemberian berbagai perlakukan sebagai stressor dan menyerupai stressor kehidupan sehari - hari yang tidak terlalu berat namun terus menerus dan dilakukan minimal selama tiga minggu (Maramis, 2015).

Lama pemberian perlakuan disesuaikan dengan siklus birahi Rattus novergicus, maka metode CUMS diberikan selama 22 hari agar didapatkan fase proestrus saat pembedahan.

Tabel 1 Uraian Stresor yang diberikan

\begin{tabular}{|c|c|c|c|c|c|}
\hline $\begin{array}{l}\text { Hari } \\
\text { ke- }\end{array}$ & $\begin{array}{l}\text { Hari } \\
\text { perlakuan }\end{array}$ & $\begin{array}{l}\text { Stressor } \\
\text { (waktu) }\end{array}$ & $\begin{array}{l}\text { Hari } \\
\text { ke- }\end{array}$ & $\begin{array}{l}\text { Hari } \\
\text { perlakuan }\end{array}$ & $\begin{array}{l}\text { Stressor } \\
\text { (waktu) }\end{array}$ \\
\hline 11 & 1 & $\begin{array}{l}\text { Dipadatkan dalam } \\
\text { satu kandang berisi } \\
5 \text { ekor tikus }(24 \\
\text { jam) }\end{array}$ & 23 & 13 & $\begin{array}{l}\text { Diikat ekornya } \\
\text { dengan benang (1 } \\
\text { jam) }\end{array}$ \\
\hline 12 & 2 & $\begin{array}{l}\text { Isolasi di ruang } \\
\text { sempit dan gelap } \\
(24 \text { jam })\end{array}$ & 24 & 14 & $\begin{array}{lll}\text { Isolasi di ruang } \\
\text { sempit dan } & \text { gelap } \\
(24 \text { jam }) & \end{array}$ \\
\hline 13 & 3 & $\begin{array}{l}\text { Diikat ekornya } \\
\text { dengan benang (1 } \\
\text { jam) }\end{array}$ & 25 & 15 & $\begin{array}{lr}\begin{array}{l}\text { Ditusuk ekornya } \\
\text { dengan }\end{array} \text { jarum } \\
\text { sepanjang } \pm 2,5 \mathrm{~cm} \\
(1 \text { jam })\end{array}$ \\
\hline 14 & 4 & $\begin{array}{l}\text { Kandang } \\
\text { dimiringkan } 45^{\circ} \quad(5 \\
\text { jam })\end{array}$ & 26 & 16 & $\begin{array}{l}\text { Immobilisasi } \\
\text { dengan wire mesh } \\
\text { restrainer ( } 2 \text { jam })\end{array}$ \\
\hline 15 & 5 & $\begin{array}{l}\text { Immobilisasi } \\
\text { dengan wire mesh } \\
\text { restrainer ( } 2 \text { jam })\end{array}$ & 27 & 17 & $\begin{array}{l}\text { Pemaparan suara } \\
\text { bising dan keras }(85 \\
-90 \mathrm{~dB}),(3 \text { jam })\end{array}$ \\
\hline 16 & 6 & $\begin{array}{l}\text { Berenang di air } \\
\left.\text { dingin } 4^{\circ} \mathrm{C} \text { ( } 3 \text { me ait }\right)\end{array}$ & 28 & 18 & $\begin{array}{l}\text { Paparan sinar terang } \\
300-400 \text { lux (4 } \\
\text { watt) dilakukan } 2 x \\
\text { sehari ( } 45 \text { menit) }\end{array}$ \\
\hline 17 & 7 & Tanpa stresor & 29 & 19 & $\begin{array}{l}\text { Dipadatkan dalam } \\
\text { satu kandang berisi } \\
5 \text { ekor tikus ( } 24 \\
\text { jam) }\end{array}$ \\
\hline 18 & 8 & $\begin{array}{l}\text { Dipadatkan dalam } \\
\text { satu kandang berisi } \\
5 \text { ekor tikus ( } 24 \\
\text { jam) }\end{array}$ & 30 & 20 & $\begin{array}{l}\text { Berenang di air } \\
\text { dingin ( } 3 \text { menit) }\end{array}$ \\
\hline 19 & 9 & $\begin{array}{l}\text { Paparan sinar terang } \\
300-400 \text { lux }(4 \\
\text { watt) dilakukan } 2 x\end{array}$ & 31 & 21 & $\begin{array}{lr}\text { Ditusuk } & \text { ekornya } \\
\text { dengan } & \text { jarum } \\
\text { sepanjang } & \pm 2,5 \mathrm{~cm}\end{array}$ \\
\hline
\end{tabular}




\begin{tabular}{|c|c|c|c|c|c|}
\hline & & sehari (45 menit) & & & (1 jam) \\
\hline 20 & 10 & $\begin{array}{l}\text { Pemaparan suara } \\
\text { bising dan keras }(85 \\
-90 \mathrm{~dB}),(3 \text { jam })\end{array}$ & 32 & 22 & $\begin{array}{l}\text { Berenang di air } \\
\text { dingin ( } 3 \text { menit })\end{array}$ \\
\hline 21 & 11 & Tanpa Stresor & 33 & - & $\begin{array}{l}\text { Visualisasi vaginal } \\
\text { plug dan Terminasi }\end{array}$ \\
\hline 22 & 12 & $\begin{array}{l}\text { Immobilisasi } \\
\text { dengan wire mesh } \\
\text { restrainer }(2 \text { jam })\end{array}$ & & & \\
\hline
\end{tabular}

efek stres akut.

\section{Pemeriksaan histologis}

Sampel jaringan ovarium kanan dan kiri diambil dengan pembedahan abdomen. Selanjutnya pembuatan preparat dan teknik pewarnaan hematosiklin eosin.

Cara mengevaluasi tebal lapisan sel granulosa adalah dengan mengamati sel berbentuk kuboid yang mengelilingi oosit pada folikel.

Pengukuran secara histologi tebal lapisan sel granulosa folikel antral di bawah mikroskop dengan menggunakan mikrometer

\section{HASIL DAN DISKUSI}

Gambaran histologi folikel ovarium pada unit sampel satu kelompok kontrol (K1), yang tertera pada gambar 1 menunjukkan terdapat seluruh fase folikel, yakni : folikel primer (a), folikel sekunder (b), folikel antral (c), folikel pre-ovulatory (d) dan folikel atretic (e).

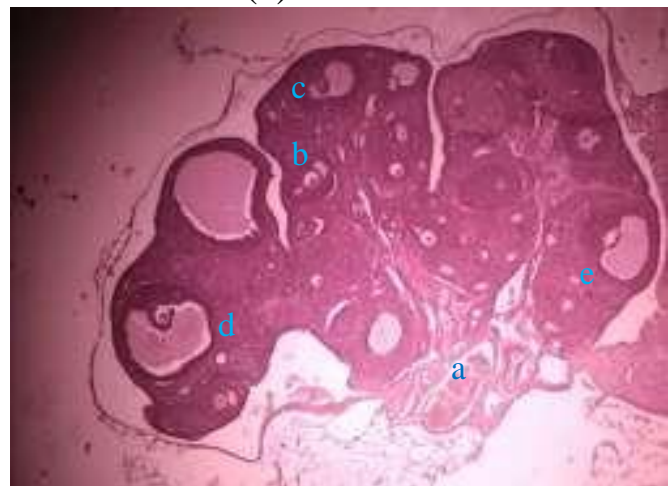

Gambar 1 Gambaran Histologi Folikel Ovarium Kelompok Kontrol (K1)
Gambaran histologi folikel ovarium pada unit sampel delapan kelompok perlakuan (P8), yang tertera pada gambar 2 menunjukkan hanya terdapat tiga fase folikel, yakni : folikel primer (a), folikel sekunder (b) dan folikel atretic (e). pada unit sampel ini tidak ditemukan fase folikel antral dan preovulatory.

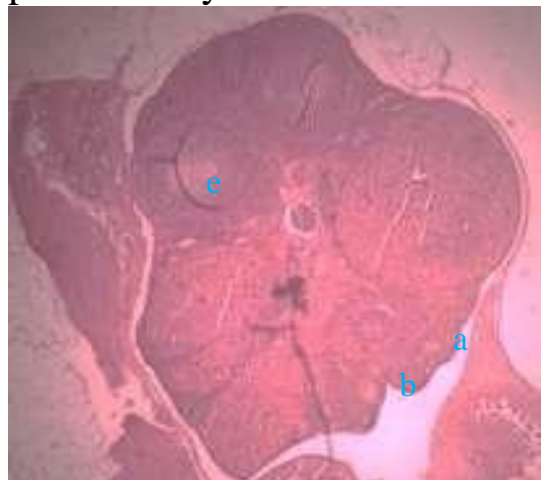

Gambar 2 Gambaran Histologi Folikel Ovarium Kelompok Perlakuan (P8) pada Pembesaran 100x dengan Mikroskop Cahaya

Pengukuran secara histologi tebal lapisan sel granulosa folikel antral di bawah mikroskop dengan menggunakan mikrometer dapat dilihat seperti pada gambar 3 . 


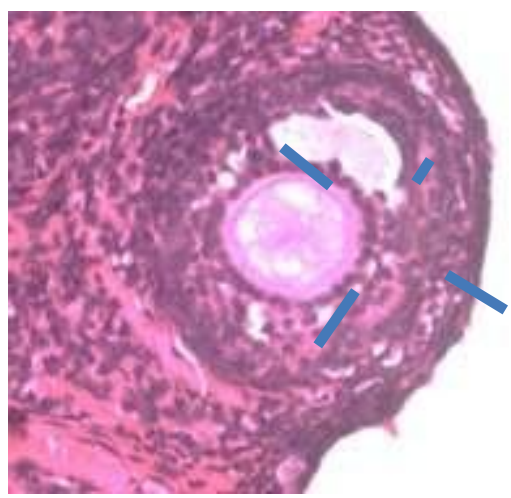

Gambar 3 Pengukuran Tebal Lapisan Sel Granulosa Folikel Antral pada Pembesaran 400x dengan Mikroskop Cahaya

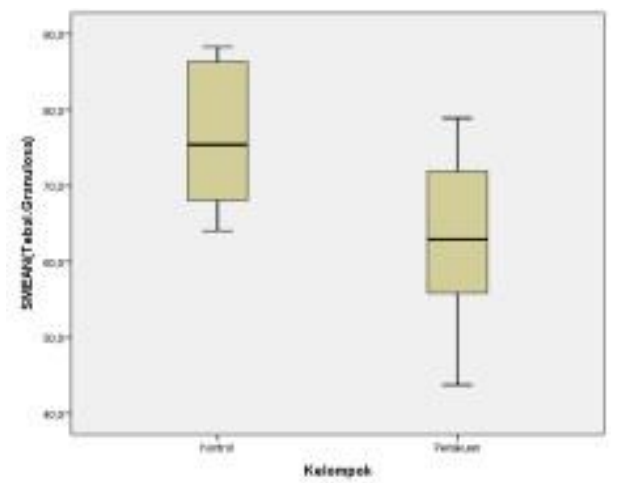

Gambar 4 Distribusi Tebal Lapisan Sel Granulosa

Folikel Antral

Gambar 4 menunjukkan bahwa tebal lapisan sel granulosa kelompok kontrol mengalami penurunan dibanding dengan kelompok perlakuan.

Data deskriptif tebal lapisan sel granulosa folikel antral dapat dilihat pada tabel 2.

Tabel 2 Data Deskriptif Tebal Lapisan

Sel Granulosa Folikel Antral

\begin{tabular}{|l|l|l|}
\hline & Kontrol & Perlakuan \\
\hline Mean \pm SD & $76.49 \pm 9.74$ & $62.99 \pm 11.45$ \\
\hline Median & 75.39 & 62.89 \\
\hline Minimal & 64.10 & 43.8 \\
\hline Maksimal & 88.30 & 78.9 \\
\hline
\end{tabular}

Secara deskriptif tampak perbedaan diantara kedua kelompok.

Data hasil penelitian terlebih dahulu diuji normalitasnya menggunakan uji Shapiro-Wilk. Berdasarkan hasil perhitungan menunjukkan bahwa masing - masing data tebal lapisan sel granulosa kelompok kontrol dan kelompok perlakuan berdistribusi normal dengan nilai $\mathrm{p}$ berturut - turut : dan

Selanjutnya pengujian hipotesis dilakukan dengan uji Independent $\mathrm{T}$ Test. Hasil uji dalam $\alpha=0.05$, nilai $\mathrm{T}_{\text {hitung }}=2.540$, nilai

( ), dapat disimpulkan menolak $\mathrm{H}_{0}$ (ada perbedaan signifikan). Maka dapat diartikan terdapat penurunan signifikan tebal sel granulosa folikel antral antara kelompok kontrol dibanding kelompok perlakuan.

Hal ini membuktikan bahwa stres yang terjadi secara kronis dapat mengakibatkan penurunan tebal lapisan sel granulosa. Sel granulosa berperan penting dalam proses maturasi folikel karena berhubungan dengan produksi hormon steroid, faktor pertumbuhan dan berperan penting dalam proses atresia folikel (Gupta et al., 2008; Myrnawati, 2012 dan Qiu et al., 2013).

Sel granulosa ovarium merupakan sel somatik folikel dimana asal, perkembangan dan fungsi dari sel-sel ini secara erat terkait dengan diferensiasi gamet betina, pembentukan ovarium dan kemajuan normal dari siklus reproduksi wanita (Baumgarten and Carlos, 2018). Perubahan pada siklus sel granulosa dianggap bertanggungjawab terhadap terganggunya pertumbuhan folikel dan maturasi oosit. (Gupta et al., 2008; Myrnawati, 2012 dan Qiu et al., 2013).

Bahkan dalam penelitiannya, Qiu et al. (2013) membuktikan bahwa atresia folikel dimulai dengan terjadinya apoptosis sel granulosa. Studi tentang jalur yang mengatur kematian sel dari ekstra seluler masih menjadi persoalan yang rumit, karena 
jalur yang sama sering digunakan untuk mengirimkan sinyal yang diperlukan untuk pertumbuhan dan diferensiasi sel. Sinyal eksternal, seperti faktor trofik dan hormon, dapat mengaktifkan atau menekan program kematian sel (Carou et al., 2017).

Dalam penelitian ini belum diketahui apakah terjadi peningkatan jumlah apopotosis sel granulosa pada Rattus norvegicus model stres kronis.

Namun gangguan homeostasis sel sehingga proliferasi sel granulosa terganggu telah dipastikan terjadi karena kondisi stres kronis.

Gangguan homeostasis sel granulosa dapat terjadi karena lemahnya stimulus hormon (Carou, et al., 2017), terutama hormon gonadotropin. Aktivitas $\mathrm{CRH}$ yang berlebihan di hipotalamus, sebagai respon terhadap stres, menjadi mekanisme untuk supresi GnRH (Whirledge, 2010).

\section{SIMPULAN DAN SARAN}

Stres yang terjadi secara kronis dapat menyebabkan penurunan tebal lapisan sel granulosa folikel antral. Akibatnya kualitas folikulogenesis mungkin saja terganggu.

Diperlukan penelitian lebih lanjut terkait gangguan folikulogenesis yang terjadi sebagai akibat stres kronis.

\section{Ucapan Terima kasih}

1. Dr. Hermanto Tri Joewono, dr., Sp.OG (K), selaku ketua Program Studi Magister Ilmu Kesehatan Reproduksi FK Unair

2. Kedua orang tua penulis, Drs. Djaka Purwanto, M.MPd dan Agung Kridyastuti, S.Pd, M.MPd

3. Prof. Dr. Soetojo, dr., Sp.U selaku dekan FK Unair Surabaya

4. Prof. Dr. Mohammad Nasih, SE., MT., Ak., CMA., selaku Rektor Universitas Airlangga Surabaya
5. Dr. Bambang Purwanto,dr., M.Kes dan Dr. Widjiati,drh., M.Si, selaku staf pengajar program studi Magister Ilmu Kesehatan Reproduksi FK Unair

6. Prof. Dr. I Ketut Sudiana, drs., M.Si dan Dr. Agung Dwi Wahyu Widodo, dr., M.Kes selaku staf pengajar program magister FK UNAIR.

7. Staf sekretariat pascasarjana FK Unair

8. Staf Departemen Biologi Fakultas Sains dan Teknologi UNAIR

9. Andina Bella Rahadi Putri selaku tim dalam penelitian

10. Serta rekan - rekan mahasiswa Magister Ilmu Kesehatan Reproduksi angkatan 2016 dan 2015 ganjil FK Unair

\section{DAFTAR PUSTAKA}

1. Fritz, Marc A dan Leon Speroff. 2011. Clinical Gynecologic Endocrinology and Infertility $8^{\text {th }}$ Edition. Philadelphia : Lippincott Williams \& Wilkins

2. Myrnawati, Mira. 2012. Ekspresi Growth Differentiation Factor-9 (GDF-9) Kompleks Oosit-Kumulus Sapi Pada Kultur Zalir Peritoneum Penderita Infertl dengan Endometriosis [Laporan Penelitian]. Surabaya. Program Dokter Spesialis Universitas Airlangga. 73 hal

3. Whirledge Shannon dan John A. Cidlowski. 2010. Glucocorticoids, stress, and fertility. National Institute of Health. Minerva endocrinol. 35(2):109-25.

4. Hendarto, Hendy. 2012. Profil TNF- $\alpha$, GDF-9 dan Hyaluronan pada Gangguan Folikulogenesis sebagai Gambaran Penurunan Kualitas Oosit Pasien Infertil dengan Endometriosis [Disertasi]. 
Surabaya. Program Pascasarjana Universitas Airlangga

5. Setiyono, Awik, Hendy Hendarto, Budi Prasetyo, Margarita M. Maramis. 2015. Pengaruh Tingkat Stres dan Kadar Kortisol dengan Jumlah Folikel Dominan pada Penderita Infertilitas yag Menjalani Fertilisasi Invitro. Majalah Obstetri \& Ginekologi. 23(3): $128-131$

6. Li, Sophie dan Bronwyn M. Graham. 2017. Why are women so vulnerable to anxiety, traumarelated and stress-related disorders? The potential role of sex hormones. The Lancet Psychiatry. 4 (1) : $73-82$

7. Scarlet D., N.Ille, R. Ertl, B.G. Alves, G.D.A. Gastal, S.O. Paiva, M.O. Gastal, E.L. Gastal, dan C. Aurich. 2017. Glucocorticoid Metabolism in Equine Follicles and Oocytes. Domestic Animal Endocrinology. $59: 11-12$

8. Rosdianto, Aziz Mardanarian. 2016. Kinerja Reproduksi Tikus Putih (Rattus norvegicus sp.) Betina Setelah Pemberian Jamu Kesuburan [Tesis]. Bogor. Sekolah Pascasarjana Institut Pertanian Bogor. 54 hal.

9. Maramis, Margarita Maria. 2015. Mekanisme Gangguan Fungsi Memori Kerja Spasial dan Fleksibilitas Kognitif Melalui HSP70, IL-6,5-HT,BDNF dan pCREB Pada Model Tikus Putih (Rattus norvegicus) Depresi [Disertasi]. Surabaya. Program Pascasarjana Universitas Airlangga. 104 hal.
10. Qiu, Mingning, Fusheng Quan, Chengquan Han, Bin Wu, Jun Liu, Zhongcai Yang, Feng Su, Yong Zhang. 2013. Effect of Granulosa Cells on Steroidogenesis, Proliferation and Apoptosis of Stromal Cells and Theca Cells Derived from The Goat Ovary. The Journal of Steroid Biochemistry and Molecular Biology. 138 : 325

11. Carou, M.C., P.R. Cruzans, A. Maruri, M.G. Farina, C.D. Fiorito, G. Olea, D.M Lombardo. 2017. Apoptosis of Bovine Granulosa Cells : Intracellular Pathways and Differentiation. Acta Hictochemica. 119 (5) : 462 - 470

12. Da Costa, Nathalia Nogueira, Karynne Nazaré Lins Brito, Priscila di Paula Bessa Santana, Marcela da Silva Cordeiro, Thiago Velasco Guimarães Silva, Alessandra Ximenes Santos, Priscilla do Carmo Ramos, Simone do Socorro Damasceno Santos, William Alan King, Moyses dos Santos Miranda dan Otávio Mitio Ohashi. 2016. Effect of Cortisol on Bovine Oocyte Maturation and Embryo Development In Vitro. Theriogenology. $85: 323$ - 32

13. Campbel. 2013. Biologi Edisi 9. Wulandari, Damaring Tyas, penerjemah; Handani, H. Wibi, ed. Jakarta : Erlangga. Terjemahan dari : Biology Nine edition

14. Guyton, Ermita I. Ibrahim Ilyas editorial. 2016. Guyton dan Hall : Buku Ajar Fisiologi Kedokteran Edisi Revisi Berwarna Ke-12. Singapura : Elsevier Singapore 